\title{
A Project-based Learning curricular approach in a Production Engineering Program
}

\author{
Simone Borges Simão Monteiro ${ }^{\mathrm{a} *}$, Ana Carla Bittencourt Reis ${ }^{\mathrm{a}}$, João Mello da Silva ${ }^{\mathrm{a}}$, \\ João Carlos Felix Souza ${ }^{\mathrm{a}}$ \\ aniversidade de Brasília, Brasília, DF, Brazil \\ *simoneborges@unb.br
}

\begin{abstract}
The Industrial Engineering undergraduate program offered at the University of Brasilia was structured on Project Based Learning ( $\mathrm{PBL}$ ) methodology. This innovative educational proposal allows the students to deploy their technical competencies through real problem solving situations. The methodology also stimulates the development of the students' soft skills, by exposing them to a challenging environment. At the end of each project, the results are presented to an external agent, and are subsequently implemented. The objective of this paper is to present the evolution of the PSP courses, which adopt as guidelines both the PMBOK project management framework, as well as content from specific technical courses related to the project's subject. One other relevant aspect of the PSP courses is their involvement of both undergraduate and graduate students from different Engineering areas, such as Industrial, Mechanical and Civil Engineering, which serves to foster a more holistic and integrated problem-solving skillset.
\end{abstract}

Keywords

Engineering education. Industrial engineering. Production System Project (PSP).

How to cite this article: Monteiro, S. B. S., Reis, A. C. B., Silva, J. M., \& Souza, J. C. F. (2017). A Project-based Learning curricular approach in a Production Engineering Program. Production, 27(spe), e20162261. http://dx.doi.org/10.1590/01036513.226116

Received: Oct. 14, 2016; Accepted: June 26, 2017

\section{Introduction}

The acquisition of technical knowledge, with its subsequent application in the context of professional activities, is essential for developing an engineering student's essential skillset. According to Soares et al. (2014), most examples of practical experience present themselves only in the final years of a student's education, as well as in the first moments after graduation. The author stipulates that, in essence, students are deprived of the opportunity to develop their abilities over the course of their academic programs, mainly by not applying the retained theories in a way that associates technical content with their professional fields.

Much has been researched in order to develop new teaching and learning models that generate more effective results. Fernandes et al. (2010) highlight the growing importance given to these new models, as well as to student-focused education. The central idea affirms that the teacher should cease being the center of the learning process, yielding the focus instead to the student, who in turn will develop new capacities that go beyond simply memorizing raw information. The emphasis on managing projects leads to the development, in students, of a set of transversal abilities, in addition to purely technical skills.

As a central theme of this work, the PBL (Project Based Learning) approach is presented as an applied methodology that encourages students to develop their own knowledge through active learning, and to interact with their environment by either working independently or in teams, while the professor guides them. According to Ríos et al. (2010), current theory suggests that the skills learned by students through the PBL 
approach are intrinsically linked to the acquisition of knowledge that can be applied in a professional environment, in improving existing skills, and for problem solving as a whole.

Project Based Learning utilizes continuous questioning as a teaching and learning technique. This particular strategy has been adopted by the University of Brasilia (UnB) in its Industrial Engineering course. The use of this approach encourages the student to seek knowledge by proposing solutions to real problems, introduced by external agents. The student becomes the subject of the learning process, as his or her learning depends on the constant search for new knowledge, technologies, methods, techniques and tools that can be used in carrying out activities that will permit them to arrive at feasible solutions.

The PBL approach provides the student with a deeper understanding of the studied content, as it puts into practice the theoretical concepts and strategies for problem solving. At the same time, it fosters the development of multidisciplinary capabilities related to communication, leadership, management, and the development of a reasoned critical thinking (Witt et al., 2006; De los Ríos-Carmenado et al., 2015; Miranda, 2004). According to Barell (2007), there is an effective increase in students' performance, due to both the greater retention of information available, and to the motivation and interest that is fostered by resolving real-life issues.

The main purpose of this study is to present the practice of PBL as applied in the Industrial Engineering Program at the University of Brasília, in Brazil. This new learning process methodology has been applied in seven of the program's courses, and mirrors various techniques adopted in other universities around the world, such as in Aalborg, Denmark, in Minho, Portugal, and other European universities (Felder \& Brent, 2010; Guerra \& Kolmos, 2011).

As such, section 2 at first describes the Project Based Learning approach itself, while section 3 describes the application of PBL in UnB's Industrial Engineering undergraduate program. Section 4 describes the obtained results and, lastly, section 5 presents the final considerations.

\section{The Project Based Learning approach}

The Project Based Learning approach is one of various teaching and learning approaches mentioned in literature. Some examples of the active learning approach are Inquiry Learning, Problem Based Learning, Project Based Learning, Case-Based Teaching, Discovery Learning, and Just-in-Time Teaching (Prince \& Felder, 2006).

In the approach known as Inquiry learning, students are faced with questions to be answered, problems to be solved, or observations to be explained. The goal is for individuals to learn to formulate questions, identify and gather evidence, systematically present results, analyze and interpret these results, and draw conclusions.

In a Problem Based Learning approach, students are given a poorly structured real-world problem, and work in teams in order to identify the learning objectives and to develop a viable solution, while their teachers act as facilitators.

The models integrating Project Based Learning have as their scientific basis a development of learning processes in which students are not merely passive recipients of knowledge (Chinowsky et al., 2006). The PBL approach has allowed for the adaptation of methodological aspects developed in teaching real problems (De los Ríos-Carmenado et al., 2015).

Through Case-based teaching, students analyze situations that involve problem solving and decision-making, such as diagnosing technical problems, formulating strategies, and making business management decisions.

Discovery learning is an inquiry-based approach in which students are given a question to answer, a problem to solve, or a set of observations to explain. They work independently in order to complete their tasks and to define the consequences of the results obtained.

Just-in-Time Teaching is an approach that combines Web-based technology and active learning methods. A few hours before class, students must complete online tasks in which they answer a set of questions. The teacher reviews the questions before class and corrects their answers (Prince \& Felder, 2006).

The work of Ríos et al. (2010) on the evolution of the PBL approach until its adoption in the European Higher Education Area (EHEA) lists three main advantages in applying this methodology. First of all, it facilitates training in technical, personal and contextual skills. In order to solve real-world problems in the professional sphere, collaborative learning must be facilitated through the integration of teaching and research. For the authors, Project Based learning is presented as the most appropriate educational methodology for the development of abilities, and for connecting the university environment with professional practices. Moreover, this process of teaching and learning requires a more active position from both teachers and students. It also represents a greater degree of responsibility for the students themselves, especially concerning their own learning process. 
According to Kapusuz \& Can (2014), the PBL approach is one of several methods that have been applied specifically to the field of engineering studies, in which the goal is to achieve the successful integration of engineers to real life contexts.

As mentioned, PBL is a learning methodology based on projects, which according to Thomas (2000), needs to consider five crucial aspects. First, projects must be seen as a central part of, and not only peripheral to, the course curriculum. Secondly, projects should be focused on questions or problems that drive students to identify the core concepts and the principles of a course. Next, projects should engage students in constructive research. Lastly, they should be student-driven to some significant degree, while also presented in a realistic, as opposed to an overly academic, fashion. Accordingly, Section 2.1 describes the general implementation of the PBL approach in engineering programs.

\subsection{PBL in engineering programs}

In the last few years, there has been a significant surge in the implementation of the PBL approach in engineering education. Programs in this field have gained prominence by serving as examples of the methodology's application, while generating positive results in the teaching and learning processes, both in the undergraduate and post-graduate levels.

The motivating factors influencing the use of the PBL approach in engineering courses have been diverse. Its increasing influence in courses such as electrical, electronics, automation, industrial, software, telecommunications and nanotechnology engineering is motivated by various reasons. The first is the necessity to graduate engineers capable of dealing with industrial problems, who are able to face new technological challenges (Bellmunt et al., 2006). Second is the need to implement best practices and innovations in engineering education (Somerville et al., 2005). These serve to enhance students' depth and breadth of knowledge, professionalism, sense of community, ability to troubleshoot, and their aptitude for innovation (Macias, 2012). There has also been a need to increase students' participation and motivation in relation to their classes, with the introduction of more practical examples (Ponsa et al., 2009; Macías-Guarasa et al., 2006). The necessity to develop soft skills, such as leadership, communication and teamwork has also been identified (Sancho et al., 2009; Macías-Guarasa et al., 2006; Costa et al., 2007). Moreover, there has been a drive towards integrating future engineers with the real world environment (Vallim et al., 2006; Hosseinzadeh \& Hesamzadeh, 2012). Further encouragement has been seen due to the success of PBL in engineering courses around the world (Mantri et al., 2008). Lastly, these applications have satisfied the current increasing demands for undergraduate education (Mitchell et al., 2010).

As to the mechanical, mechatronics and industrial engineering courses, the main motivation for the application of the PBL approach is the need to provide students with the ability to deal with real-life industrial problems (Wang et al., 2012; Gibson, 2001; Soares et al., 2013). Other aspects have also motivated the application of the PBL approach, such as the goal to provide a clear idea of the fields of knowledge related to mechanical engineering, and to demonstrate to students the importance and necessity of measured analysis in order to find optimal solutions (Frank et al., 2003). Researchers have also pointed out the need to improve the rates of content retention, and to develop skills related to transversal competencies (Cano et al., 2006), team work and communication, as well as the traditional technical abilities (Soares et al., 2013).

In Civil Engineering, there has been an emphasis towards developing students' skills in project management, communication, teamwork, innovative and critical thinking, creativity, design capability and multidisciplinary competencies, allowing for a greater utilization of multiple engineering concepts (Chinowsky et al., 2006; Fruchter \& Lewis, 2003; Aparicio \& Ruiz-Teran, 2007; Becerick-Gerber et al., 2012).

In Chemical Engineering, while the acquisition of knowledge linked to the main disciplines is considered to be of the utmost importance, some consideration is also given to social and management skills (Witt et al., 2006). In addition, students are also instructed to focus on the development of personal and professional competencies, as well as on the continuous monitoring of technological developments in their respective field of study (Crosthwaite et al., 2006; Gomes et al. 2006).

In general, various other factors are also seen as motivating the use of the PBL approach, such as efforts to increase students' engagement (Smith et al., 2005), and to promote their intellectual development and creative thinking skills (Huntzinger et al., 2007). There has also been an effort to drive students towards being more closely responsible for their own learning process (Soares et al., 2014), mainly by having a curriculum that is centered on their particular needs (Galand et al., 2010).

As previously exemplified, universities that have decided to implement the PBL approach in engineering courses have been influenced by various motivating factors, while its application has seen many different contexts. 
Purdue University, in the USA, has employed the PBL approach in extra-curricular undergraduate projects, with a focus on non-profit organizations, which have presented technologically oriented challenges. The efforts have resulted in students with better teamwork, communication, project planning and leadership abilities (Coyle et al., 2005). Other institutions such as Penn State (USA), the University of Washington (USA) and the University of Puerto Rico-Mayagüez (Porto Rico) have also studied the application of the PBL approach in undergraduate courses. These institutions have endeavored to stimulate innovation in engineering education, while also providing high quality, hands-on experience. They have concluded that these concepts must be present in every learning phase, and have applied the principles of PBL in order to provide better personal experiences, improving both students' abilities and knowledge (Lamancusa et al., 2008).

The Université Catholique de Louvain, in Belgium, conducted an initial survey as a means to evaluate a curriculum which was more focused on the students, and directed towards improving their skillsets. As a positive result, they observed better rates of coordination and support from the professors, and improved academic results from their students. However, the survey also pointed to a higher student workload, with no significant increase in motivation (Galand et al., 2010).

The School of Engineering at Deakin University, in Geelong, Australia, also conducted research related to the investigation of industrial and academic requirements for students, with a focus on improving design-oriented skills. Their surveys included freshman and senior students, in which the definition of engineering for the latter group included "the use of science and technology to benefit society" (Chandrasekaran et al., 2013).

The Technical University of Madrid, in Spain, developed an approach for designing its Electronic Systems curricula that aimed at making electronic subjects more appealing to students. Their approach proposed the development of multidisciplinary projects using Project Based Learning. Subsequently, results pointed to an increase in students' interest and affinity for electronics, with an improvement in both academic results and in the acquisition of more advanced knowledge needed to develop increasingly sophisticated and realistic electronic systems. Many other universities, from different countries, have researched the use of the PBL approach in the engineering field, with promising results.

In the PBL approach, students are able to acquire their own knowledge through active learning and by interacting with their environment (Thomas, 2000). This work thus presents one further context in which Project Based learning plays an important role, and where learning is achieved specifically through Production Systems Projects (PSP) courses, which continuously relate theory to practice as part of the Industrial Engineering undergraduate program at the University of Brasilia, in Brazil.

\section{PSP in the Industrial Engineering program at the University of Brasilia}

The University of Brasilia (UnB)'s Industrial Engineering undergraduate program presents an innovative curriculum, which is based on the Project Based learning methodology (PBL). The program has been designed with a length of 12 semesters. It first began in the second half of 2009, and graduated its first group of engineers in the second semester of 2014. The program features eight courses labeled Production Systems Projects (PSP), all of which apply the PBL approach, and are held from the $3^{\text {rd }}$ to the $5^{\text {th }}$ year of the program.

According to Zindel et al. (2012), project courses are those based upon main anchors. Figure 1 illustrates the PSP courses, with their respective technical anchors.
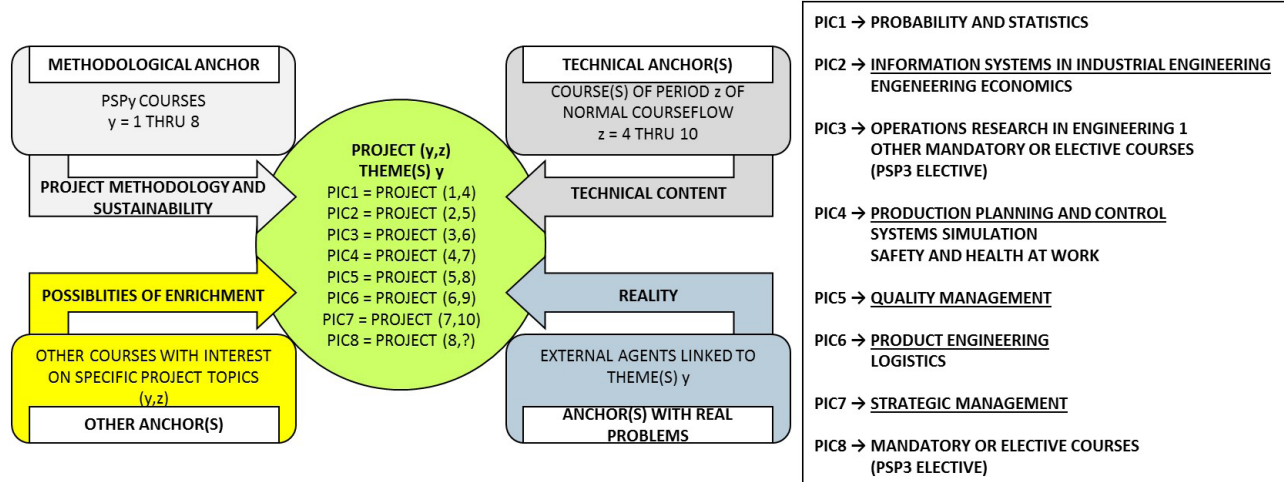

Figure 1. General Scheme for Project Anchors (y, z) Production System. Source: Adapted from Zindel et al. (2012). 
As previously mentioned, the PSP structure of UnB's Industrial Engineering undergraduate program is based upon four anchors, which support the projects' development. The first of these are the Methodological Anchors, which are project courses related to active learning, utilizing project management techniques that focus on sustainability. The Technical Anchors are courses which provide a basis for the project's execution, such as Probability and Statistics, Production Planning and Control, Quality Management, and Strategic Management, among others. One special set of Anchors provide real-world problems. These are public or private sector external representatives who introduce real-life case studies to the university's environment. The given problems are linked to the technical anchors, and at the start of each semester, the program's professors search for new external agents that can provide students with novel challenges. The final anchor group is associated with other possibilities for knowledge enrichment, and is comprised of specific projects introduced in other Engineering courses, all of which are presented as "knowledge integrators".

For instance, a Project $(y, z)$ may have one or several y subjects, where y is the corresponding PSP course $(y=1$ to 8$)$ and $z$ identifies one of the semesters in the normal course structure ( $z=4$ to 10$)$. The problems arising from the Project courses $(y, z)$ are assigned to each project team, which normally consists of 5 to 6 members. These individuals are responsible for identifying the specific problems detected by external stakeholders and for preparing answers and solutions throughout the semester. The project team's solution for a given problem requires a direct interface between the knowledge acquired from the external agent stakeholder and the student's review of research sources, as well as the integration of multidisciplinary knowledge and teamwork abilities. The Project courses $(1,4)$, are the starting point of a series of eight projects, and were first offered as standard disciplines in the first semester of 2011.

By the end of 2015, 243 projects had already been developed, involving several external agents. As a result, students have worked alongside various public Brazilian institutions, such as the International Labor Organization (ILO), the National Social Security Institute (INSS), the Ministries of Planning and Defense, the Federal Data Processing Service (SERPRO), the Brazilian Institute of Museums (IBRAM), the Brazilian Revenue Service, the Center for Event Selection and Promotion (CESPE), the University Hospital of Brasilia (HUB), and the University of Brasilia 's Data Processing Center (CPD/UnB). They have also cooperated with private manufacturing companies such as Marina Bolos, Consist Sistema de Implantes, Gravia Indústria de Perfilados de Aços Ltda, Medley Pharmaceutical Industry Ltda, and Cervejaria Stady Beer.

In traditional classrooms, students engage in learning in a mostly passive manner, mainly by observing their instructors. At times, they follow along classroom presentations, and when questioned about a subject, often consult their assigned textbooks. This passive form of student engagement often leads to inferior rates of retention of exposed knowledge. Singhal et al. (1997), in mentioning the "Learning Pyramid", demonstrated that knowledge retention rates, when considering material presented in class, depend mainly on the different teaching and learning methods applied. While a traditional class structure often results in an average retention rate of 5\%, the application of other techniques, such as those which involve students teaching their colleagues, will typically correspond to retention rates approximating 90\%.

Similarly, activities that relate to practice by doing, and which involve the PBL methodology and include project activities, can result in a 75\% retention rate. These project activities, which have become the focus of new curricula in engineering programs, are no longer seen as graduation events held at the end of a course, often aimed at synthesizing knowledge. Currently, they are developed over the duration of the course by student teams, and have become the guiding principle in students' training (Singhal et al., 1997).

Although the main purpose for imposing a team arrangement in PSP courses has been to provide teamwork experience for students, this arrangement also provides them with elements of the "teaching others" and "practice by doing" approaches.

The initial proposal of the PSP courses was to develop projects that included issues related to sustainable activities, and that were linked to the technical content of their anchor courses. There was also the need for involving external agents, who would present concrete problems, and to relate the course to others linked to specific topics of the project, as presented in Figure 1. Over time, new aspects were incorporated into the dynamics of PSPs in the UnB's Industrial Engineering program.

Production systems generate goods or services. As services are more difficult to measure than goods, their ratings are often associated with customer expectations and perceptions. The development of UnB's Industrial Engineering undergraduate course curriculum can be understood as a process of service production in an educational context; specifically, the production process of knowledge acquired by the student through a PBL approach.

As in all production processes, there are inputs and outputs. In the program's curriculum, the input is the undergraduate student who attends the fourth semester of the normal program structure. The purpose of this 
new curriculum is to generate, as an output, an engineer with an expertise in project management, who possesses an aptitude in technical and transversal skills, acquired through the practice of solving real-world problems arising from external agents. Over the course of the program, learning becomes progressively more effective, due to the increasing complexity of the projects (Zindel et al., 2012; Aquere et al., 2012).

According to Tobin et al. (1990), projects must be sufficiently attractive as to promote the full engagement of the project team towards solving the real-world problem, which in turn serves to promote student learning. Therefore, the student must understand his or her responsibilities both within the group and in relation to normal classroom activities. The instructing professor, in turn, is responsible for adopting a role of facilitator in an environment that will foster student learning.

As referenced by Lima et al. (2012), the expected profile of an Industrial Engineering student involves playing different roles in projects and focusing on solving real-world problems. Additionally, the student must develop an understanding related to the production of services in general and public services in particular, as well as to aspects of industrial production. This includes understanding the role of different government and State institutions - including international organizations - and establishing a personal overview of the world, in order to understand their own position in a regional and global context. In achieving these objectives, the University of Brasilia hopes to serve its role as a prominent university in both a regional and national context.

The design of this new curriculum leads students towards acquiring expertise in project management and in developing transversal skills in the execution of each of the projects, while ensuring that the learning process becomes increasingly more effective, due to the projects' progressive degree of difficulty. Figure 2 illustrates the level of learning required for a student throughout the PSPs (Lima et al., 2012).

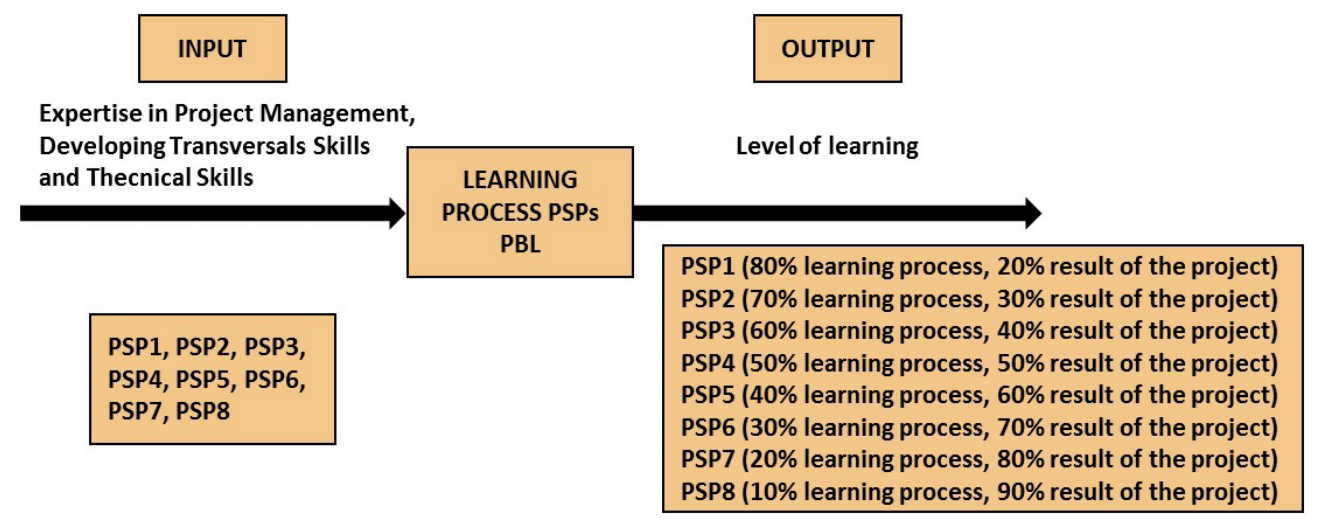

Figure 2. Learning process of PSPs through the PBL approach. Source: Adapted from Lima et al. (2012).

The concept of the learning process is based on the fact that, as students attend each of the PSP courses, they gradually assimilate the set of prerequisite knowledge required. In the PSP1 course, the evaluation of the learning process represents $80 \%$ of the given grade, while the project result itself accounts for only $20 \%$. As this is the students' first contact with the course, they will have only begun the process of knowledge acquisition. As students complete PSP8 (the last of the required project courses), they will have been expected to acquire significant expertise in project management, as a result of practicing the required skills over the 7 previous semesters. Therefore, the evaluation will be based mainly upon the project's result (90\%), as the learning process (10\%) will have already been internalized by the individual.

In order to meet the demands of all PSPs, from PSP1 through PSP8 in the normal program flow, an average of 60 teams are formed per semester. These groups work through various themes in projects developed in assorted areas of knowledge, involving many stakeholders. However, this requires a large amount of external agents available to present real problems for students. This in turn demands great dedication on the part of the course professors who, while normally preoccupied with teaching activities, research, and extension programs, must also assume the responsibility for selecting external agents, who will be available to oversee projects in their 
respective courses over the subsequent semester. In addition, one professor might need to guide 10 to 12 teams in the first semester.

While the PBL project developed by the program in relation to the PSPs is seen as an excellent learning method, the course flow in the Industrial Engineering program initially outgrew the capacity of the professors themselves. As a result, new forms of work were proposed. Firstly, it was established that students of the PSP8 course must become monitors for previous classes, assisting professors in instructing the more junior teams, thus putting into practice what they have learned in their previous PSP courses. Secondly, graduate students from UnB's Professional Master's Program in Applied Computer Science were asked to present their real-life research topics for students in the PSP courses, thus facilitating the professors' tasks related to identifying external stakeholders for the next semester.

During each semester, generally eight PSP courses are offered. PSP3, originally linked to the technical anchor Operational Research course, is an elective. In the second semester of 2015, the PSP8 elective course was also developed, which was primarily linked to the technical anchor Statistical Process Control (SPC) course. The initiative in creating the PSP8 course arose from the need to establish a feedback channel, so that students from the seven previous PSPs might be able to share their experiences with more junior PSP students. Those who attended PSP8 have typically already developed projects in the areas of Statistics, Information Systems, Operations Research, Planning and Production Control, Quality Management, Product Engineering and Strategic Management. The objective, then, is for students who attend a PSP8 course to become monitors for PSP1 and PSP5 teams. As such, they will be able to assist in developing PSP1 projects that utilize tools for troubleshooting Statistical Control of Processes, and PSP5 projects related to Statistics, Probability and Quality. It is worth noting that the grade evaluation method for the PSP8 course is closely linked to the activities developed by students in the PSP1 and PSP5 projects. Therefore, the assessment is able to relate to grades from other courses in the Department of Industrial Engineering.

As previously noted, the Industrial Engineering undergraduate program has developed a partnership with the Graduate Studies Program in the university's Computer Science Department. Specifically, the partnership involves collaboration with students from the Professional Master's Degree in Applied Computer Science (MPCA), which possesses three research foci (IT Infrastructure, Software Engineering and Risk Management). The Industrial Engineering Department has assumed the coordination of the program's Risk Management research focus. As a result, several Department professors have participated in the Program, and are conducting research in its related areas. In order to introduce real-life problems to PSPs students, aspiring MPCA program graduates are invited to present their research topics to the PSP teams, as their issues often originate from the public or private institutions in which they are employed. As a result, several of the external agents participating in the PSP1, PSP2, and PSP5 courses are MPCA students. For their part, Master's students often find advantages in presenting their research problems to be addressed by the undergraduate PSP students, particularly as their supervising professor will often integrate their dissertation's research planning with the activities performed by the PSP teams. In this manner, the exchange of knowledge becomes mutually beneficial, as the undergraduate engineering student is introduced to different problems linked to the field of Risk Management in Information Technology, while the Master's students, as mentors to their undergraduate peers, are eventually able to benefit from the solutions proposed by the PSP teams.

Figure 3 presents the elements that support the PSP course structure.

With these new project course initiatives, students at the final stages of the program (those attending the final PSP8 course) have had the opportunity to diffuse their knowledge to teams who are presently attending the first and middle steps of the PSP course flow. This layout also acts as a motivating factor to other students, who know that they, in the future, will also be performing as instructors. Moreover, the participation of MPCA Master's students in the project courses has introduced to the undergraduates the opportunity to conduct more advanced scientific research.

\subsection{Structuring the PSP courses}

The PSP courses hold weekly 100-minute meetings, with the class dynamics following a predetermined schedule. On the first day of the course, students are supplied with the course syllabus, and given instructions as to how to conduct their activities. On the second day, they are introduced to the external agents, who may be students of the MPCA Master's Program, or individuals who are either new or who have participated in previous semesters' PSP courses. These individuals will then present students with the topics that will be available for the new semester. The topics will then be ranked by each student in order of preference, and the teams will in turn be allocated according to each individual's chosen priorities. 


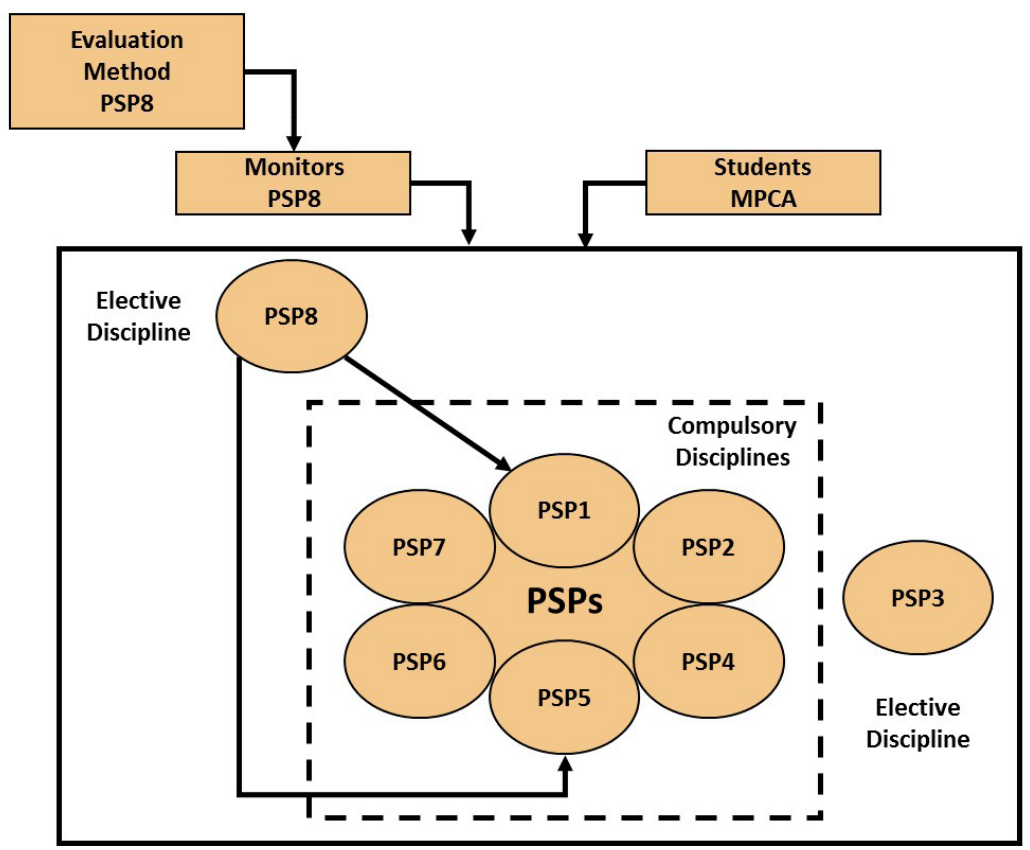

Figure 3. A new approach for structuring Project courses (PSP).

As an example, the PSP5 course, related to the technical Quality Management in Industrial Engineering anchor course, will introduce students to a new project management method, based on the Agile methodology. On the third day of this course, students will be introduced to the concept of the Agile Method and its application. The following week, teams will convene in order to initiate project planning activities, using the Business Case in the initiation phase, the Project Model Canvas in the planning phase, and the Sprints for project execution. The team should clearly state the form of planning and quality control of the product or service that will be delivered. Over the course of the semester's classes, there will be three control points: the presentations of the preliminary project, the intermediate project and the final project, as can be seen in Figure 4.

The Preliminary Project delivery requires only a PowerPoint presentation of the Business Case and the Project Model Canvas. For the Intermediate Project, students must submit a written summary, divided into a technical report describing the activities' progress, and a project follow-up document. Notwithstanding the use of the Agile methodology, the team is expected to detail both their workflow and the progress in achieving their set of targets. In addition, an oral presentation will be expected. In the final delivery, beyond what is presented in the Intermediate Project, the teams will also submit a research article detailing the proposed solutions applied in solving the initial problem. The delivery structure presented in Figure 4 is based on the model initially defined in the first PSP1 course offered in 2011. Incidentally, this is the same structure presently adopted in the other PSP courses.

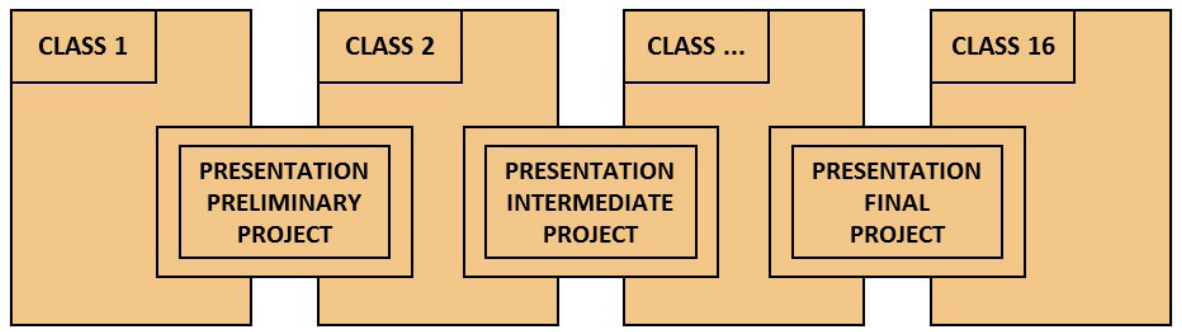

Figure 4. Structure of the Project course (PSP) deliveries. 
In addition to the formal deliveries, peer review from other team members is an important component of the students' final grades. This last assessment serves to evaluate a student's performance in accordance to other team members' perceptions. Peer review also serves to contrast the grade determined by a student's peers with the grade attributed by the student to him or herself. This leads to identifying possible gaps in the student's performance, as evaluated by both his peers and his own self-assessment, evidencing any specific criterion that needs improvement.

The evaluation consists of three steps: the preliminary project (PP), the intermediate project (IP) and the final project (FP). The final grade is calculated by the following Expression 1.

$$
\begin{aligned}
& F G=0.2 P P((0.2 O P+0.8 M D P) * P E)+0.4 I P((0.2 O P+0.2 M D P+0.6 T R) * P E) \\
& +0.4 F P((0.2 O P+0.2 M D P+0.2 T E+0.2 S A) * F C)
\end{aligned}
$$

In essence, the final grade includes an oral presentation (OP), the project's monitoring document (MDP), the technical report (TR) and the academic article (SA). These factors are multiplied by the peer evaluation grade (PE). The peer evaluation criteria are: communication (flow of information, interpersonal communication, language used); leadership (motivation, interpersonal relationship, proactivity), effectiveness (availability to solve problems, assertiveness in executing tasks, and resilience), professionalism (attendance and punctuality in meetings, punctuality in tasks, ability to work in teams), management capacity (planning, organization, and resource location) and cognitive ability (identification of problems and proposing solutions, utilization of adequate techniques).

In the final delivery, students will write an academic article presenting the results of the project developed during the semester, following the National Congress of Industrial Engineering (ENEGEP) website template. The objective of this article is to promote scientific research and, at the same time, help students differentiate between a technical report and a scientific publication.

\section{Results from the evaluation of PBL at UnB}

Over the course of the seven years since the development of the Industrial Engineering undergraduate program, and six years after the implementation of the principles of PBL, the results can easily be assessed as very positive. This was at first demonstrated by the evaluation results given by INEP (Instituto Nacional de Estudos e Pesquisas Educacionais Anísio Teixeira, 2016). The INEP website presents indicators that comprise both the information system and that the regulatory process enforced by MEC (Brazil's Ministry of Education), ensuring the transparency of the data related to the quality of higher education throughout the country. One of the indicators that evaluate the quality of undergraduate programs is the National Student Performance Examination (ENADE). Students are evaluated when first enrolling and after graduating from the educational system, via an examination consisting of general and specific questions. Auditors have conducted on-site visits at UnB's campus in order to assess the institution's infrastructure, educational conditions and physical facilities, as well as the faculty's profile, and the didactic-pedagogical organization of each individual program.

Furthermore, a periodic evaluation of the courses is required by the nation's National Higher Education System (SINAES). This specific evaluation is a requirement in order to receive official authorization, certification and renewal of educational activities.

The UnB's Industrial Engineering program received its first certification assessment by INEP in the second semester of 2014, which was notably positive; on a scale from 1 to 5, the program received a grade of 4.33 .

Regarding the ENADE evaluation, UnB's Industrial Engineering program students have obtained the second highest score among all Brazilian Industrial Engineering courses. On the same 1 to 5 scale, the institution was granted a score of 4.835, second only to the Federal University of Rio de Janeiro (UFRJ)'s score of 4.929. Of the 29 students initially selected for evaluation, 27 were able to attend the exam (two were medically justified absentees).

In essence, and in accordance with the results obtained, it is possible to affirm that the PBL-based teaching methodology adopted by UnB's Industrial Engineering Program has been an essential factor for obtaining the results given by the INEP and ENADE evaluations. As evidenced by these institutions, the undergraduate program can be considered as one of the finest of its kind in Brazil.

With the application of this new methodology, students are able to assimilate the subject matter by searching for knowledge that is specifically aimed at solving a given problem. Their final objective is to arrive at a feasible solution that serves the needs of an external stakeholder. Learning by applying solutions found over the course 
of conducting projects has been a highlighted as an important factor in determining students' success when entering a professional environment. Through the mixture of academic and real-life experiences gained in the PSP courses, they can consider themselves as being better prepared, not only by possessing technical and cross-competency knowledge in the Industrial Engineering field, but also by having developed interpersonal abilities such as leadership, communication, proactivity, project management and problem-solving skills.

The results of the learning methodology were further evidenced by studies conducted alongside PSP5 students in the second semester of 2016, labeled "Quality Indicators for Industrial Engineering". The project was aimed at producing an internal benchmark, based on the INEP criteria, which would evaluate various proposals for improving the university's quality of education. The evaluation thus consisted of criteria related to professors' performance, the quality of services offered by the Department, and the efficiency in management of both the Program and PSP courses.

The study was conducted through an initial questionnaire and further data collection techniques. The questionnaire itself was applied to 342 students, representing $63 \%$ of the total population of 550 individuals. It included all courses offered by the Program, excluding only those taught by more than one professor, or offered by another Department. In addition, the questionnaire contained specific questions related to the PSP courses.

As a result, and considering a scale from 1 to 5 (in which 5 is the best result), 61.5\% of the professors were considered to be "very good". In relation to the Program's staff, services offered and management structure, $89 \%$ of the students considered themselves completely satisfied. Considering the practical application of knowledge from the technical anchor courses in the PSP classes, although 68\% of the students related improved retention of learned concepts, 71\% considered that two of the units did not reward them properly for their efforts. The general satisfaction index related to the class was 3.64. This evaluation proved invaluable in determining opportunities for improvement, and the Structuring Teacher Core (STC) is already implementing many of the proposed actions. Some of these include a review of the courses' prerequisites, the inclusion of mandatory subjects, and the expansion of the number of units for the PSP classes, among others.

In general, the results obtained in the PSP courses are satisfactory, as demonstrated by the aforementioned survey. For their part, professors have related improvements in students' performance, leading to a higher engagement rate, which served to further raise the quality of the University of Brasilia's most distinguished engineering program. By structuring itself in accordance with the principles of PBL, and with the support of the PSP courses linked to technical anchor subjects, the university's Production Engineering program has ensured a continuous learning process that improves its graduating students' chances of obtaining leadership positions as they enter the workforce.

\section{Final considerations}

The University of Brasilia's Industrial Engineering undergraduate program has developed an innovative curriculum, aimed at training highly qualified engineering students, who possess the ability to manage projects utilizing both traditional PMBOK-centered project management methods as well as Agile methodologies.

The Production Systems Project (PSP) disciplines are considered to be the Program's flagship courses. By applying Project Based Learning methods, they have enabled students to face challenges, solve problems, make data-driven decisions and produce results through the use of project monitoring, leadership skills, and teamwork, among other abilities (Dym et al., 2005). The problems dealt within the PSP courses are those faced by real-world public or private organizations. In each semester, the lndustrial Engineering program fosters the study of a new diversity of themes that support the development of projects studied over the eight PSP courses, by adopting the practice of obtaining research topics from graduate students of the Professional Master's program in Applied Computer Science (MPCA). In addition, undergraduate students undertaking the final PSP course are encouraged to become mentors to students who are in the early stages of the program.

With the adoption of these practices, the program has been able to increase the number of subjects offered to students, and to include undergraduate students as participants in the ongoing development of each project. This is turn facilitates the overall management of the courses by the professors, especially in light of the increasing number of teams with each passing semester.

In the future, the program expects to introduce a PSP course journal, which will contain publications related to the most outstanding PSP projects developed in each semester. In addition, a graduate student is developing an initial PSP projects database, which professors will use in order to input students' grades, and which they in turn will utilize for reviewing their performance and delivering project documents. With this database, the coordinator of the course, along with the guiding professors, may be able to monitor the progress of each student in real time. 
The results of the program were further acknowledged by the outstanding evaluations obtained by INEP (4.33) in December 2014, as well as the overall ENADE (4.835) National Examination score, which serves as a benchmark for Brazil's Production Engineering programs. These results are derived from the innovative structure of the program, as well as from its adoption of active learning methodologies such as PBL, which propel students' development towards excellence. They serve to officially cement its reputation as one of the top Industrial Engineering undergraduate programs in Brazil.

\section{References}

Aparicio, A. C., \& Ruiz-Teran, A. M. (2007). Tradition and innovation in teaching structural design in civil engineering. Journal of Professional Issues in Engineering Education and Practice, 133(4), 340-349. http://dx.doi.org/10.1061/(ASCE) 1052-3928(2007)133:4(340).

Aquere, A. L., Mesquita, D., Lima, R. M., Monteiro, S. B. S., \& Zindel, M. (2012). Coordination of student teams focused on project. International Journal of Engineering Education, 28, 859. Retrieved in 24 August 2016, from http://hdl.handle.net/1822/18818

Barell, J. (2007). Problem-based learning: an inquiry approach (2nd ed.). Thousand Oaks: Corwin.

Becerick-Gerber, B., Ku, K., \& Jazizadeh, F. (2012). BIM-Enabled virtual and collaborative construction engineering and management. Journal of Professional lssues in Engineering Education and Practice, 138(3), 234-245. http://dx.doi.org/10.1061/(ASCE)El.19435541.0000098.

Bellmunt, O. G., Miracle, D. M., Arellano, S. G., Sumper, A., \& Andreu, A. S. (2006). A distance PLC programming course employing a remote laboratory based on a flexible manufacturing cell. IEEE Transactions on Education, 49(2), 278-284. http://dx.doi.org/10.1109/ TE.2006.873982.

Cano, J. L., Lidón, l., Rebollar, R., Roman, P., \& Saenz, M. J. (2006). Student groups solving real-life projects: a case study of experiential learning. International Journal of Engineering Education, 22(6), 1252-1260. Retrieved in 24 August 2016, from http://www.ijee. ie/contents/c220606.html

Chandrasekaran, S., Stojcevski, A., Littlefair, G., \& Joordens, M. (2013). Project-oriented design-based learning: aligning students' views with industry needs. International Journal of Engineering Education, 29(5), 1109-1118. Retrieved in 02 March 2017, from http:// www.ijee.ie/contents/c290513.html

Chinowsky, P. S., Brown, H., Szajnman, A., \& Realph, A. (2006). Developing knowledge landscapes through project-based learning. Journal of Professional Issues in Engineering Education and Practice, 132(2), 118-124. http://dx.doi.org/10.1061/(ASCE) 10523928(2006) 132:2(118).

Costa, L. R. J., Honkala, M., \& Lehtovuori, A. (2007). Applying the problem-based learning approach to teach elementary circuit analysis. IEEE Transactions on Education, 50(1), 41-48. http://dx.doi.org/10.1109/TE.2006.886455.

Coyle, E. J., Jamieson, L. H., \& Oakes, W. C. (2005). EPICS: engineering projects in community sevice. International Journal of Engineering Education, 21(1), 139-150. Retrieved in 24 August 2016, from http://www.ijee.ie/contents/c210105.html

Crosthwaite, C., Cameron, l., Lant, P., \& Litster, J. (2006). Balancing curriculum processes and content in a project centred curriculum: in pursuit of graduate attributes. Education for Chemical Engineers, 1(1), 39-48. http://dx.doi.org/10.1205/ece.05002.

De los Ríos-Carmenado, l., López, F. R., \& García, C. P. (2015). Promoting professional project management skills in engineering higher education: project-based learning (PBL) strategy. International Journal of Engineering Education, 31(1), 184-198. Retrieved in 24 August 2016, from http://www.ijee.ie/contents/c310115B.html

Dym, C. L., Agogino, A. M., Eris, O., Frey, D. D., \& Leifer, L. J. (2005). Engineering design thinking, teaching, and learning. Journal of Engineering Education, 94(1), 103-120. http://dx.doi.org/10.1002/j.2168-9830.2005.tb00832.x.

Felder, R. M., \& Brent, R. (2010). The National Effective Teaching Institute: assessment of impact and implications for faculty development. Journal of Engineering Education, 99(2), 121-134. http://dx.doi.org/10.1002/j.2168-9830.2010.tb01049.x.

Fernandes, S. R., Flores, M. A., \& Lima, R. M. (2010). A aprendizagem baseada em projectos interdisciplinares: avaliação do impacto de uma experiência no ensino de engenharia. Avaliação, 15(3), 59-86.

Frank, M., Lavy, l., \& Elata, D. (2003). Implementing the project-based learning approach in an academic engineering course. International Journal of Technology and Design Education, 13(3), 273-288. http://dx.doi.org/10.1023/A:1026192113732.

Fruchter, R., \& Lewis, S. (2003). Mentoring models in support of $\mathrm{P}^{5} \mathrm{BL}$ in architecture / engineering / construction global teamwork. International Journal of Engineering Education, 19(5), 663-671. Retrieved in 24 August 2016, from http://www.ijee.ie/contents/ c190503.html

Galand, B., Raucent, B., \& Frenay, M. (2010). Engineering students' self-regulation, study strategies, and motivation believes in traditional and problem-based curricula. International Journal of Engineering Education, 26(3), 523-534. Retrieved in 24 August 2016, from http://www.ijee.ie/contents/c260310.html

Gibson, 1. S. (2001). Group project work in engineering design: learning goals and their assessment. International Journal of Engineering Education, 173), 261-266. Retrieved in 24 August 2016, from http://www.ijee.ie/contents/c170301.html

Gomes, V. G., Barton, G. W., Petrie, J. G., Romagnoli, J., Holt, P., Abbas, A., Cohen, B., Harris, A. T., Haynes, B. S., Langrish, T. A. G., Orellana, J., See, H. T., Valix, M., \& White, D. (2006). Chemical engineering curriculum renewal. Education for Chemical Engineers, 1(1), 116-125. http://dx.doi.org/10.1205/ece.06020.

Guerra, A., \& Kolmos, A. (2011). Comparing problem based learning models: suggestions for their implementation. In Proceedings of the 3rd International Research Symposium on PBL, Coventry University, UK.

Hosseinzadeh, N., \& Hesamzadeh, M. R. (2012). Application of project-based learning (PBL) to the teaching of electrical power systems engineering. IEEE Transactions on Education, 55(4), 495-501. http://dx.doi.org/10.1109/TE.2012.2191588.

Huntzinger, D. N., Hutchins, M. J., Gierke, J. S., \& Sutherland, J. W. (2007). Enabling sustainable thinking in undergraduate engineering education. International Journal of Engineering Education, 23(2), 218-230. 
Instituto Nacional de Estudos e Pesquisas Educacionais Anísio Teixeira - INEP. (2016). Retrieved in 20 March 2010, from http://portal. inep.gov.br

Kapusuz, K. Y., \& Can, S. (2014). A survey on lifelong learning and project-based learning among engineering students. Procedia: Social and Behavioral Sciences, 116, 4187-4192. http://dx.doi.org/10.1016/j.sbspro.2014.01.914.

Lamancusa, J. S., Zayas, J. L., Soyster, A. L., Morell, L., \& Jorgensen, J. (2008). The learning factory: industry-partnered active learning. Journal of Engineering Education, 97(1), 5-11. http://dx.doi.org/10.1002/j.2168-9830.2008.tb00949.x.

Lima, R. M., Mello da Silva, J., Hattum-Janssen, N., Monteiro, S. B. S., \& Souza, J. C. F. (2012). Project-based learning course design: a service design approach. International Jornal of Services and Operations Management, 11(3), 292-313. http://dx.doi.org/10.1504/ IJSOM.2012.045660.

Macías, J. A. (2012). Enhancing project-based learning in software engineering lab teaching trough an e-portfolio approach. IEEE Transactions on Education, 55(4), 502-507. http://dx.doi.org/10.1109/TE.2012.2191787.

Macías-Guarasa, J., Montero, J. M., San-Segundo, R., Araujo, A., \& Nieto-Taladriz, O. (2006). A project-based learning approach to design Electronic Systems Curricula. IEEE Transactions on Education, 49(3), 389-397. http://dx.doi.org/10.1109/TE.2006.879784.

Mantri, A., Dutt, S., Gupta, J. P., \& Chitkara, M. (2008). Design and evaluation of a PBL-based course in analog electronics. IEEE Transactions on Education, 51(4), 432-438. http://dx.doi.org/10.1109/TE.2007.912525.

Miranda, M. A. (2004). The grounding of a discipline: cognition and instruction in technology education. International Journal of Technology and Design Education, 14(1), 61-77. http://dx.doi.org/10.1023/B:ITDE.0000007363.44114.3b.

Mitchell, J. E., Canavan, B., \& Smith, J. (2010). Problem-based learning in communication systems: student perceptions and achievement. IEEE Transactions on Education, 53(4), 587-594. http://dx.doi.org/10.1109/TE.2009.2036158.

Ponsa, P., Amante, B., Roman, J. A., Oliver, S., Díaz, M., \& Vives, J. (2009). Higher education challenges: introduction of active methodologies in engineering curricula. International Journal of Engineering Education, 25(4), 799-813. Retrieved in 24 August 2016, from http://www.jjee.ie/contents/c250409.html

Prince, M. J., \& Felder, R. M. (2006). Inductive teaching and learning methods: definitions, comparisons, and research bases. Journal of Engineering Education, 95(2), 123-138. http://dx.doi.org/10.1002/j.2168-9830.2006.tb00884.x.

Ríos, 1., Cazorla, A., Díaz-Puente, J. M., \& Yagüe, J. L. (2010). Project-based learning in engineering higher education: two decades of teaching competences in real environments. Procedia: Social and Behavioral Sciences, 2(2), 1368-1378. http://dx.doi.org/10.1016/j. sbspro.2010.03.202.

Sancho, P., Fuentes-Fernandez, R., Gomez-Martin, P. P., \& Fernandez-Manjon, B. (2009). Applying multiplayer role-based learning in engineering education: three case studies to analyze the impact on students' performance. International Journal of Engineering Education, 25(4), 665-679. Retrieved in 2 March 2017, from http://www.e-ucm.es/drafts/e-UCM_draft_136.pdf

Singhal, A. C., Bellamy, L., \& McNeill, B. (1997). A new approach to engineering education. Arizona: Arizona State University, pp. 88.

Smith, K. A., Sheppard, S. D., Johnson, D. W., \& Johnson, R. T. (2005). Pedagogies of engagement: classroom-based practices. Journal of Engineering Education, 94(1), 1-15. http://dx.doi.org/10.1002/j.2168-9830.2005.tb00831.x.

Soares, F., Leão, C. P., Carvalho, V., Vasconcelos, R. M., \& Costa, S. (2014). Automation and control remote laboratory: a pedagogical tool. International Journal of Electrical Engineering Education, 51(1), 54-67. http://dx.doi.org/10.7227/1JEEE.51.1.5.

Soares, F. O., Sepúlveda, M. J., Monteiro, S., Lima, R. M., \& Dinis-Carvalho, J. (2013). An integrated project of entrepreneurship and innovation in engineering Education. Mechatronics, 23(8), 987-996. http://dx.doi.org/10.1016/j.mechatronics.2012.08.005.

Somerville, M., Anderson, D., Berbeco, H., Bourne, J. R., Crisman, J., Dabby, D., Donis-Keller, H., Holt, S. S., Kerns, S., Kerns, D. V., Martello, R., Miller, R. K., Moody, M., Pratt, G., Pratt, J. C., Shea, C., Schiffman, S., Spence, S., Stein, L. A., Stolk, J. D., Storey, B. D., Tilley, B., Vandiver, B., \& Zastavker, Y. (2005). The Olin curriculum: thinking toward the future. IEEE Transactions on Education, 48(1), 198-205. http://dx.doi.org/10.1109/TE.2004.842905.

Thomas, J. W. (2000). A review of research on project based learning. San Rafael: The Autodesk Foundation.

Tobin, K., Kahle, J. B., \& Fraser, B. J. (1990). Windows into science classrooms: problems associated with higher-level cognitive learning. London: The Falmer Press.

Vallim, M. B. R., Farines, J. M., \& Cury, J. E. R. (2006). Practicing engineering in a freshman introductory course. IEEE Transactions on Engineering, 49(1), 74-79. http://dx.doi.org/10.1109/TE.2005.856157.

Wang, Y., Yu, Y., Wiedmann, H., Xie, N., Xie, C., Jiang, W., \& Feng, X. (2012). Project based learning in mechatronics education in close collaboration with industrial: methodologies, examples and experiences. Mechatronics, 22(6), 862-869. http://dx.doi.org/10.1016/j. mechatronics.2012.05.005.

Witt, H., Alabart, J. R., Giralt, F., Herrero, J., Vernis, L., \& Medir, M. (2006). A competency-based educational model in a chemical engineering school. International Journal of Engineering Education, 22(2), 218-235. Retrieved in 24 August March 2016, from http://www.ijee.ie/contents/c220206.html

Zindel, M. L., Mello da Silva, J., Souza, J. C. F., Monteiro, S. B. S., \& Oliveira, E. C. (2012). A new approach in engineering education: the design-centric curriculum at the University of Brasília-Brazil. International Journal of Basic \& Applied Sciences, 12(5), 97-102. Retrieved in 24 August 2016, from http://www.ijens.org/Vol_12_1_05/127105-8585-lJBAS-lJENS.pdf 